\title{
UPAYA PENINGKATAN PENGHASILAN TAMBAHAN HOME INDUSTRI JENANG CIKRU SEBAGAI PENDIDIKAN BERBASIS PELESTARIAN KEARIFAN LOKAL DI DESA BANYUBIRU, KECAMATAN BANYUBIRU, KABUPATEN SEMARANG, PROVINSI JAWA TENGAH
}

\author{
Ismatul Khasanah $^{1}$, Ari Widyaningrum ${ }^{2}$, Nila Kusumaningtyas ${ }^{3}$ \\ Universitas PGRI Semarang \\ e-mail: ismatulkhasanahbejo@gmail.com
}

\begin{abstract}
Banyubiru village is located around the Rawa Pening area, where there are many water plants such as swamp lotus that thrives in this area. Lotus has many benefits and potential that can be processed for the welfare of the Banyubiru community. As one of the results of processing from lotus flower seeds which become Banyubiru's special culinary, namely jenang cikru which is a pearl of local wisdom that needs to be preserved and regenerated. There were several vocations targeted at the service location, one of which was home industry-based vocational. Home industry-based vocational training was prepared for the target of selling women, and vocational training based on swamp lotus cultivation as the main ingredient in making jenang cikru was prepared for all residents. The focus of the program is to increase the income of members of the Mitra Family through a superior program to develop the Jenang Cikru home industry. Formation of program clusters which includes: (1). The cluster of swamp lotus cultivation and the process of making Jenang Cikru, (2). The marketing cluster results are synergistic and integrated to produce swamp lotus cultivation and processing of jenang. Continuous guarantee programs are carried out through the development of cooperation with various elements of society, academics, stakeholders, and industry. The conclusion of this service activity is traditional culinary preservation which is the hallmark of Banyubiru Village so that it can improve and lift the economy of the home industry in jenang cikru.
\end{abstract}

Key words: Home, Industry, Jenang Cikru.

\begin{abstract}
Abstrak
Desa Banyubiru terletak di sekitar kawasan Rawa Pening, dimana banyak tumbuhan air seperti teratai rawa yang tumbuh subur di kawasan ini. Teratai memiliki banyak manfaat dan potensi yang dapat diolah untuk kesejahteraan masyarakat Banyubiru. Seperti salah satu hasil pengolahan dari biji bunga teratai yang menjadi kuliner khas Banyubiru, yakni jenang cikru yang merupakan kearifan lokal yang perlu dilestarikan dan diregenerasi. Ada beberapa vokasi yang disasar pada lokasi pengabdian, salah satunya vokasi berbasis industri rumah tangga. Vokasi berbasis industri rumah tangga dipersiapkan untuk sasaran ibu-ibu yang senang berjualan, dan vokasi yang berbasis budidaya teratai rawa sebagai bahan utama pembuatan jenang cikru dipersiapkan untuk semua penduduk. Fokus program adalah peningkatan penghasilan anggota Keluarga Mitra melalui program unggulan pengembangan home industri Jenang Cikru. Pembentukan kluster program yang meliputi: (1). Kluster budidaya teratai rawa dan proses pembuatan Jenang Cikru, (2). Kluster pemasaran hasil yang sinergis dan terpadu untuk menghasilkan budidaya teratai rawa dan pengolahan jenang cikru. Penjaminan berkelanjutan program dilakukan melalui pengembangan kerjasama dengan berbagai elemen masyarakat, akademisi, stake holder, dan industri. Simpulan dari kegiatan pengabdian ini yakni pelestarian kuliner tradisional yang menjadi ciri khas Desa Banyubiru, sehingga dapat meningkatkan dan mengangkat perekonomian home industri jenang cikru.
\end{abstract}

Kata Kunci: Rumah, Industri, Jenang Cikru 


\section{PENDAHULUAN}

Desa Banyubiru merupakan salah satu wilayah Negara Republik Indonesia yang terletak di Banyubiru Sub District, Semarang District, Provinsi Jawa Tengah. Publikasi Banyubiru Sub District dalam Angka 2015 dapat dilihat bahwa wilayah Banyubiru Sub District merupakan wilayah yang cukup luas, yakni dengan angka 54,415 km², dan terdiri dari 10 desa, yakni Banyubiru, Gedong, Kebondowo, Kebumen, Sepakung, Kemambang, Ngrapah, Rowoboni, Tegaron, dan Wirogomo. Semarang District merupakan salah satu dari 29 kabupaten dan 6 kota di Provinsi Jawa Tengah (sumber: https://semarangkab.bps.go.id, diunduh 21 Mei 2017). Jarak antara Kantor Bupati Semarang ke Banyubiru Sub District sekitar $13 \mathrm{Km}$. Luas Wilayah Desa Banyubiru 677.087 Ha. Desa Banyubiru memiliki 9 dusun, yakni Krajan, Kampung Rapet, Randusari, Tegalwuni, Cerbonan, Demakan, Pancuran, Dangkel, dan Tawang Rejo. Desa Banyubiru yang terletak antara Kota Salatiga dengan Ambarawa, mempunyai batas-batas sebagai berikut : Sebelah Utara: Kelurahan Pojok Sari. Sebelah Barat: Desa Rapah / Desa Brongkol. Sebelah Selatan: Desa Wirogomo Sebelah Timur: Desa Kebondowo.

Secara umum Desa Banyubiru adalah daerah agraris baik pertanian basah $50 \%$ dan pertanian kering $35 \%$ serta $15 \%$ daerah rawa-rawa, Dengan demikian sumber makanan untuk sektor peternakan juga melimpah. Untuk Sektor Pertanian padi sangat baik karena wiliyah Desa Banyubiru hampir $(50 \%)$ seluruh lahan yang landai sampai lahan dekat rawa Pening bisa ditanami padi namun pada tahun 2015 sektor pertanian mengalami penurunan produksifitas karena beberapa factor diantaranya : Bencana kekeringan, gundukan Enceng Gondok, Hama Tikus dan serangan hama wereng, ada Musim tanah tidak serentak.Namun demikian wilayah Desa Banyubiru masih bisa sebagai penyangah pangan untuk Semarang District dengan produktifits tahun 2015 kurang lebih 4.500 ton gabah basah permusim sama seperti pada tahun 2009 dan 2010, 2011, 2012 ada peningkatan dan pada tahun 2015 ini sedikit mengalami peningkatan. Selain Sektor Pertanian Desa Banyubiru juga masih punya Sektor unggulan yaitu Sektor Peternakan ada beberapa macam peternakan yang dikembangkan masyarakat diantaranya : Ternak Sapi Potong dan perah, ternak Itik, ternak kambing dan beberapa ternak lain seperti ternak burung ocehan juga masih menjanjikan. Ternak Sapi Potong sangat produktif dan masih menjanjikan mengingat bahwa sumber makanan cukup banyak dan iklim yang cocok untuk ternak Sapi dan akhir-akhir ini dikembangkan sapi perah walau belum untuk produksi susu namun hanya untuk pengadaan bibitbibit sapi. Walaupun pemasaran masih lewat pasar Tradisional.

Sektor perikanan secara tradisional sudah ada sejak dulu yaitu penangkapan ikan di danau Rawa Pening, Sektor ini hanya cukup untuk kosumsi harian dan masih ada pengembangan Sektor perikanan yang dikelola perorangan atau kelompok yaitu pengembangan perikanan dengan system tertata baik dengan kolam pemanen, semi permanent ada kolam terpal untuk pengembangan ini memang masih terbatas untuk pembenihan, pembesaran ikan Lele dan Patin saja ( untuk catatan ikan Patin sampai saat ini belum bisa dikembangan dengan baik di Desa Banyubiru).

Sektor Perkebunan baik Kopi dan Cengkeh dan tanaman Sengon masih cukup bisa dikembangkan mengingat sudah adanya sistem pola tanam dan perawatan dengan cara yang lebih baik karena sudah mendapatkan pelatihan dari instasi dan Dinas terkait, namun juga ada kekawatiran hutan di kawasan Desa Banyubiru cenderung menjadi hutan homogen Sengon karena dari nilai ekonomi lebih menjanjikan tapi hal ini juga berbahaya karena bila ada hama serangan akan sulit ditanggulangi sepeti dulu pernah terjadi serangan hama kutu loncat sehingga tanaman lamtoro dan mandingan habis, hal 
ini juga yang menjadi kekawatiran kita bersama.

Sektor UMKM belum bisa maksimal dalam menyunbangkan hasil atau incam masyarakat. Kurangnya pelatihan dan permodalan. Dan hanya Sektor perajin tahu tempe dan jamu yang masih eksis dan bertahan serta berkembang sedang Sektor yang lain belum bisa menyumbang incam pendapatan yang cukup. Ada hal yang perlu diperhatikan selama ini pelaku UMKM cenderung bisa membuat produk home industry tapi susah untuk mencari celah pemasaran karena belum ada perlindungan system dari Pemerintah Pusat, Propinsi dan Kabupaten.

Mata pencarian penduduk Desa Banyubiru Banyubiru Sub District sebagian besar sebagai pegawai swasta, pegawai negeri, petani, buruh tani, peternak dan home industri. Para pekerja di bidang pertanian tidak menuntut pendidikan yang tinggi. Ibu rumah tangga memiliki banyak waktu luang karena pekerjaan yang dikelola hanya kegiatan sehari-hari di dalam rumah. Beberapa orang ibu-ibu yang memiliki hobi memasak, mencoba membuat makanan kecil yakni jenang cikru. Awalnya hanya dikonsumsi secara pribadi dan hanya diproduksi pada waktu tertentu. Usaha yang dirintis warga ini tidak dapat berjalan dengan baik, bahkan tergolong rugi. Hal ini disebabkan karena bahan baku utama yang sangat sukar ditemui dan pemasaran yang kurang maksimal. Ketidakberhasilan home industri jenang cikru tersebut diakibatkan ada beberapa hal, terutama: (a). Ketersediaan bahan baku, (b). Pengetahuan tentang budidaya teratai rawa yang terbatas, (c). Mahalnya peralatan produksi jenang yang lebih canggih, (d). Pemasaran jenang yang sukar ditembus. Menurut ensiklopedi Indonesia industri adalah bagian dari proses produksi yang tidak secara langsung atau mendapatkan barangbarang atau bahan dasar secara kimiawi sehingga menjadikan lebih berharga utuk dipakai mausia. Memberikan batasan yang jelas pada industri, selain dibedaka npengubahan dan pengolahan bahan, juga diperhitungkan suatu kriteria lain, kompleksitas dari peralatan yang dipakai perusahaan yang mengambil bahan dasar dari alam, kemudian langsung mengolahnya melalui peralatan mekanis yang komplek (Ensiklpedi Indonesia, 1982:121). Berangkat dari kondisi di atas, Universitas PGRI Semarang memprogramkan Kuliah Kerja Nyata Pembelajaran Pemberdayaan Masyarakat di Desa Banyubiru, Banyubiru Sub District, Semarang District.

Dari hasil pra observasi dan diskusi yang dilakukan antara LPPM Universitas PGRI Semarang, Badan Pemberdayaan Masyarakat Desa sebagai penanggung jawab, Badan Perencanaan Pembangunan Daerah, Kepala Desa, pelaku UKM disepakati pelaksanaan KKN-PPM Universitas PGRI Semarang mengacu pada Peraturan dengan menggarap secara bersama-sama, sebagai berikut:

a. Peningkatan pendapatkan keluarga

b. Peningkatan pengetahuan dan keterampilan

c. Peningkatan akses pendidikan

d. Peningkatan akses terhadap informasi pasar

e. Peningkatan kualitas hidup keluarga

Ada beberapa vokasi yang dipersiapkan di Desa Banyubiru, yaitu (a).Vokasi berbasis budidaya teratai rawa sebagai bahan utama pembuatan jenang cikru, (b).Vokasi berbasis industri rumah tangga. Kedua vokasi itu akan dipersiapkan dengan sasaran yang berbeda. Vokasi berbasis industri rumah tangga dipersiapkan untuk sasaran ibuibu yang senang berjualan, dan vokasi yang berbasis peternakan budidaya teratai rawa sebagai bahan utama pembuatan jenang cikru dipersiapkan untuk semua penduduk. Vokasi atau keterampilan unggulan yang dipilih berdasarkan diskusi antara Kelompok Mitra, tokoh masyarakat, LPPM Universitas PGRI Semarang, Badan Pemberdayaan Masyarakat dan Desa Semarang District, Badan Perencanaan Pembangunan Daerah Semarang District, dan masyarakat Desa Banyubiru adalah budidaya teratai rawa sebagai bahan utama pembuatan jenang 
cikru. Hasil penelitian Izdiyana Nihlah (2011) menunjukkan adanya beberapa pengaruh dari home Industri ke perekonomian warga. Pengaruhpengaruh tersebut adalah tersedianya lapangan pekerjaan, dan meningkatnya perekonomian warga.

Adapun beberapa keunggulan home Industri menurut Haryati La Kamisi (2009:112), sebagai berikut:

a. Hanya bermodal kreativitas dan tekun pantang menyerah, seseorang dapat saja membangun home industri di rumahnya sendiri.

b. Pemasarannya sendiri akan banyak diterima berbagai kalangan.

c. Membangun home industri memang tak mudah sebab dapat jadi semuanya akan dimulai dari angka nol. Kerja keras, sabar, pantang menyerah, dan ketekunanlah kunci utamanya. Jika sudah pada termin aman, pelaku home industri kerap kali mengakui bahwa banyak sekali laba mengelola home industri di rumah sendiri.

Program dilakukan secara garis besar dan sistematis untuk dapat menyelesaikan masalah serta cara pemberdayaan masyarakat agar kegiatan dapat berlangsung berkelanjutan dapat dijabarkan sebagai berikut: Pembentukan kluster program yang meliputi: (1). Kluster budidaya teratai rawa dan proses pembuatan Jenang Cikru, (2). Kluster pemasaran hasil. Kluster yang terdiri atas dosen, mahasiswa, pemerintah kabupaten, dan masyarakat/mitra kerja ini bekerja secara sinergis dan terpadu untuk menghasilkan target/luaran/output yang telah ditentukan. Penjaminan berkelanjutan program dilakukan melalui pengembangan kerjasama (net working) dengan berbagai elemen masyarakat, akademisi, stake holder, serta industri

Pelaksanaan program didasarkan pada riset yang telah dilakukan oleh dosen, instansi terkait, dan mahasiswa TIM KKN-PPM Universitas PGRI Semarang yang terdiri atas berbagai disiplin ilmu

\section{Program Penyuluhan dan Pelatihan}

Tujuan Umum Program Penyuluhan dan Pelatihan adalah:

a. Memberikan penyuluhan tentang beberapa cara peningkatan pendapatan

b. Meningkatkan keterampilan mitra binaan dan elemen masyarakat

c. Memberikan penyuluhan tentang pengembangan produk dan pengembangan pemasaran produk

d. Demonstrasi Plotting/Pelatihan

e. Monitoring dan Evaluasi Program

\section{METODE PELAKSANAAN}

1. Persiapan dan Pembekalan.

a. Mekanisme pelaksanaan kegiatan KKN-PPM.

Untuk mencapai hasil yang optimal dilakukan beberapa kegiatan yang berkaitan dengan mekanisme pelaksanaan kegiatan KKN-PPM, sebagai berikut: (1). Pengumpulan Data, (2). Identifikasi Masalah, (3). Formulasi Kegiatan, (4). Implementasi Kegiatan, dan (5). Evaluasi Akhir.

b. Materi persiapan dan pembekalan KKN-PPM yang perlu diberikan kepada mahasiswa.

1. Pengetahuan tentang budidaya teratai rawa dan manfaat serta aneka olahan.

2. Pengetahuan tentang pengembangan produk, pemasaran dan membangun jaringan.

3. Pengetahuan sosialisasi dengan masyarakat.

\section{Pelaksanaan.}

Untuk mengefektifkan pembinaan dan pendampingan digunakan metode/cara pembentukan kluster sesuai dengan bidang binaan. Dalam program KKN-PPM kali ini membentuk 2 kluster bidang binaan yang sesuai dengan tema/topik KKN-PPM. Kluster binaan itu sebagai berikut:

a. Kluster produksi.

1. Sosialisasi dan penyuluhan kepada warga binaan tentang teknik budidaya teratai rawa, pemasaran.

2. Pelatihan pembuatan dan pengolahan jenang cikru. 
3. Pendampingan pengurusan legalisasi perizinan.

4. Diskusi dan pertemuan mingguan yang membahas masalah-masalah yang timbul.

5. Evaluasi produk, bahan baku, dan manajemen.

b. Kluster pemasaran/marketing.

1) Sosialisasi dan penyuluhan tentang pengetahuan pemasaran kepada kelompok pengepul dan petugas pemasaran.

2) Pelatihan pemasaran.

3) Launching produk.

4) Pendampingan pemasaran

5) Menentukan target capaian dan wilayah pemasaran.

6) Distribusi produk ke pangsa pasar.

\section{HASIL DAN PEMBAHASAN}

Objek dari Pengabdian pada masyarakat ini adalah ibu-ibu rumah tangga di Desa Banyubiru Banyubiru Sub District Semarang District. Sasaran dipilih dengan alasan agar dapat meningkatkan pendapatan dari home industry jenang cikru, yang ada di desa Banyubiru, Banyubiru Sub District, Semarang District. Di Desa Banyubiru terdapat 2 UMKM (Home Industry) kecil yang mengelola dan memproduk pembuatan jenang cikru. 2 kelompok ini masing-masing hanya dikelola oleh 2 keluarga kecil, yakni maksimal 4 orang dalam satu kelompok. Dalam pemrosesan produk cikru tidak dapat dilaksanakan setiap hari dan setiap waktu, hal ini dikarenakan kurangnya atau langkanya bahan baku yang digunakan untuk membuat satu loyang jenang cikru. Selain itu SDM yang memproduk rata-rata sudah berumur atau berusia di atas 40 tahunan. Hal ini membuat kuliner asli dari desa Banyubiru tersebut menjadi jarang ditemui, dan hanya ada di satu dua event/ acara di masyarakat.

Bahan baku untuk pembuatan jenang cikru berasal dari biji teratai. Nama Latin teratai Nympea. Bunga Teratai, tanaman yang tumbuh di permukaan air yang tenang. Habitat
Teratai adalah diatas air dengan kondisi cuaca yang sejuk namun cukup matahari. Akarnya menjulur kedalam air. Ciri Fisik Bunga Teratai adalah sebagai berikut: Akar teratai berongga dan berfungsi sebagai jangkar agar tanaman berdiri tegak, Batangnya berada di bawah permukaan air, sebagai penopang agar daun tetap di permukaan, daunnya berbentuk bulat tipis, lebar dengan tepi bergerigi berwarna hijau, Bunganya merupakan perpanjangan dari rimpang, terletak pada tangkai dengan gradasi warna merah mudah dan putih.

Hampir semua bagian tanaman teratai bisa digunakan sebagai bahan pangan. Daun teratai sering dipakai dalam pengobatan tradisional Cina. Daun ini bermanfaat untuk menurunkan panas, sakit kepala hingga diare. Jika daun dibakar (abunya) dapat menghentikan pendarahan pada paruparu hidung dan rahim karena efek homeostatic yang dimiliki. Selain manfaat di atas, daun teratai juga bersifat diuretic dan dapat mengobati diare. Dalam kuliner Cina, daun ini sering digunakan sebagai pembungkus makanan atau nasi agar baunya harum dan tahan lama.Selain daun, biji teratai juga sumber pangan yang potensial karena kaya akan kandungan protein. Aneka kue, minuman atau puding lebih harum dan gurih dengan menambahkan biji teratai. Selain rasanya yang gurih, biji ini juga bermanfaat untuk kesehatan jantung, limpa dan ginjal. Efek astringen (mendinginkan dan mengikat selaput lendir) yang dimiliki dimanfaatkan untuk mengobati diare kronik. Efek sedatif (menenangkan) yang dimiliki juga berguna sebagai obat insomnia dan palpitasi (detak jantung cepat). Umbi tanaman teratai yang tertanam di dalam lumpur juga sangat bermanfaat.

Melihat banyaknya manfaat di atas, tim dalam kegiatan KKN PPM mengajak masyarakat desa Banyubiru untuk mengangkat dan mempopulerkan kembali kuliner khas mereka yang 
sudah ada sejak turun temurun. Kuliner yang diangkat pada kegiatan KKN PPM ini adalah "jenang cikru" dimana jenang ini dibuat dari biji teratai liar yang hidup di rawa-rawa maupun sawah-sawah. Untuk itu kita mengambil biji bunga teratai, bijinya bisa dijadikan sebagai bahan baku untuk membuat kue, tentunya setelah diolah dulu menjadi tepung. Untuk menghasilkan tepung, kelopak bunga teratai dijemur dan dibiarkan membususk. Setelh kering bunga tersebut akan pecah dan mengeluarkan biji di dalamnya. Biji tersebut kemudian ditumbuk hingga halus, tepung ini dinamakan tepung teratai atau tepung cikru. Tekstur tepung cikru ini unik, halus berpasir.

Adapun hasil kegiatan yang dilaksanakan sebagai berikut:

1. Pembuatan Kolam Cikru sebagai wadah perkembangbiakan bahan baku

2. Pengadaan FGD perihal pembentukan dan pengelolaan manajemen UMKM serta pelatihan perijinan PIRT

3. Pelatihan (workshop) pembuatan aneka olahan berbahan baku cikru, (jenang cikru dan variannya)

\section{Pembuatan Kolam Cikru sebagai wadah perkembangbiakan bahan baku}

Pada program pengembangbiakan bahan baku, tim membuat tempat perkembangbiakan teratai terlebih dahulu. Kegiatan ini dilakukan pada tanggal 6 Juli 2018, dimana kerjasama antara pihak Desa dengan tim KKN PPM serta mahasiswa. Pihak Desa Banyubiru mendukung program dari pengabdian untuk membuat sejumlah kolam yang digunakan sebagai lahan pengembangbiakan tanaman teratai.

Untuk kolam, desa menyiapkan 8 buah kolam di dusun Cerbonan yang dialiri langsung dengan air dari Rawa Pening. Kolam desa ini dulunya dipakai untuk kolam ikan nila dengan luas 350 hektar. Dan sudah tidak dipakai dan tidak terawat selama 15 tahun belakangan. Jadi pada minggu sebelumnya masyarakat desa bekerja bakti untuk membersihkan kolam ini untuk dipakai sebagai tempat penanaman teratai rawa oleh tim KKN PPM. Bibit teratai disediakan oleh tim KKN PPM yang dikelola oleh pihak Desa berjumlah 1500 bibit yang siap disebar ke kolam, dan 23 tanaman teratai yang sudah berakar dan berbatang.

Kolam ini selama masa pengabdian di Desa Banyubiru diamati dan dirawat oleh mahasiswa KKN PPM, selanjutnya kolam ini dapat dikelola langsung oleh desa dan masyarakat desa Banyubiru.Selama kurang lebih 45 hari diamati dan dikelola oleh tim KKN PPM, kolam cikru tumbuh subur dan mulai bertunas, ada beberapa yang telah berbunga dan dapat dipanen untuk diambil bijinya.

\section{Pengadaan FGD perihal pembentukan dan pengelolaan manajemen UMKM serta pelatihan perijinan PIRT.}

Kegiatan FGD dilaksanakan pada tanggal 8 Juli 2018 di balai desa Bayubiru, Banyubiru Sub District Semarang District. Kegiatan ini dilaksanakan kerjasama TIM KKN PPM, mahasiswa KKN PPM, dan ibuibu PKK serta beberapa pemuda pemudi karang taruna desa Banyubiru. Jumlah yang hadir ada 83 orang dengan rincian, 3 DPL, 39 Mahasiswa, ibu Kepala Desa sekaligus sebagai ketua PKK Desa Banyubiru dan masyarakat. Kegiatan dipusatkan untuk masyarakat dan para pengrajin jenang cikru yang lebih terfokus ada di dusun Tegalwuni Desa Banyubiru. Pada kegiatan ini dibahas tentang bagaimana membentuk UMKM, pemenuhan persyaratan dan manajerial baik secara organisasi maupun penugasan antar lini nya. Dan tidak lupa pembekalan dari Ibu Nila Kusmaningtyas, S. T., M. Pd. tentang perijinan PIRT. Guna pemenuhan persyaratan dalam memperdagangkan hasil produksi cikru.

Pelatihan (workshop) pembuatan aneka olahan berbahan baku cikru, (jenang cikru dan variannya).

Kegiatan ini dilaksanakan oleh ibu-ibu PKK dan mahasiswa serta tim KKN 
PPM dengan mendatangkan narasumber $\mathrm{Bu}$ Aniq yang seorang pengrajin jenang dan kue bulan cikru. Workshop diadakan pada tanggal 12 juli 2018 di tempat Kediaman Bapak Kadus

Tegalwuni.

Pada workshop pelatihan pembuatan jenang cikru tidak hanya berdemo masak dalam pengolahan jenang cikru, tapi juga bagaiamana proses pemasakan cikru dari biji hingga menjadi tepung. Dan juga pelaksanaan workshop ini dilakukan dengan tujuan agar ibu-ibu baik PKK maupun UMKM dapat mengolah dan mengkreasikan produk cikru agar lebih mudah dalam melebarkan pangsa pasar.

\section{KESIMPULAN}

Berdasarkan hasil pelaksanaan kegiatan Program KKN-PPM yang berjudul "Upaya Peningkatan Penghasilan Tambahan Home Industri Jenang Cikru di Desa Banyubiru, Banyubiru Sub District, Semarang District, Provinsi Jawa Tengah", terdapat beberapa hal yang dapat disimpulkan, antara lain:

1. Program pelatihan dan pengembangbiakan cikru ini dapat diterima oleh masyarakat Desa Banyubiru dan mendorong mereka untuk melestarikan kuliner tradisional yang menjadi ciri khas desa Banyubiru.

2. Pada kegiatan Pengembangbiakan, pelatihan pembuatanjenang dan variannya serta pengembangan usaha dari jenang cikru ini dapat membantu mengangkat perekonomian keluarga desa Banyubiru, khususnya pada usaha kecil rumahan yang dikelola oleh ibu-ibu rumah tangga yang tergabung dalam PKK dan UMKM.

Saran

Saran dari pelaksanaan KKN PPM ini disampaikan kepada:

1. Bagi pengrajin/ pengusaha: diperlukan kreativitas, kesabaran dan ketelatenan yang serius dalam pengembangan bahan baku dan pengembangan usaha home industri jenang cikru.

2. Bagi pemerintah desa: hendaknya memberikan dukungan optimal dalam pelaksanaan kegiatan serta dalam penyediaan fasilitas dan media yang dibutuhkan untuk meningkatkan potensi masyarakat terutama dalam UMKM .

1. Bagi lembaga: hendaknya memberikan dukungan optimal dalam pelaksanaan kegiatan penelitian dan pengabdian terutama dalam penyediaan fasilitas dan media yang dibutuhkan untuk meningkatkan potensi peneliti dan masyarakat.

\section{DAFTAR PUSTAKA}

Bappeda Provinsi Jawa Tengah, publikasi Jawa Tengah Dalam Angka 2016, diakses tanggal 14 Mei 2017 jam 15.30 WIB.

Badan Pusat Statistik Semarang District, publikasi Semarang District Dalam Angka 2016 Dan Kecamatan Dalam Angka 2016, diakses tanggal 14 Mei 2017, jam 14.01 WIB

Jurnal Manajemen dan Kewirausahaan Vol 3, No 2, September (2001)

Kolter, Philip. 2003. Marketing Management. New Jersey: Prentice Hall.

Kolter, P., dan G. Amstrong. 1997. Prinsip-prinsip Pemasaran. Edisi Ketiga , Jilid I, Penerbit Jakarta: PT prenhallindo.

Manullang. 1981. Dasar-dasar Managemen. Jakarta: Ghalia Indonesia.

Pelly, Usman dan Asih Menanti. 1994. Teori-teori Sosial Budaya. Jakarta: Departemen Pedidikan dan Kebudayaan.

Tambunan, Tulus T. H. 2001. Perekonomian Indonesia: Teori dan Temuan Empiris. Jakarta: Ghalia Indonesia.

Tim Penyusun. 1982. Ensiklopedi Indonesia. Jakarta : Ichtiar Baru-Van Houve.

Tjiptono, Fandy. 1997.Strategi Pemasaran, Edisi Kedua, Yogyakarta: Penerbit Andi- Offset. Wahyu. 1995. Pengantar Ilmu Sosial. Banjarmasin: Lambang Amangkurat University Press. 